Александар В. Петровић

Универзитет у Источном Сарајеву

Филозофски факултет Пале

Катедра за германистику

aleksandar.petrovic@ffuis.edu.ba

https://doi.org/10.18485/ai_san_o_gradu.2019.ch3

82:004.738.5

\title{
КИБЕРНЕТСКИ РЕАЛИЗАМ \\ И САВРЕМЕНИ ЕСКАПИЗАМ
}

У савремено доба, када се градови толико шире да из њих више није могуће побјећи, када и остаци природе представљају опасност готово као и сам град, интернет постаје платформа у којој је савремени ескапизам могућ. Њемачки књижевник-блогер Албан Николај Хербст даје на свом књижевном блогу Die Dschungel. Anderswelt примјер савременог ескапизма. У својој теорији кибернетског реализма Хербст доноси многе креативне и иновативне увиде у књижевност новог реализма повезујући савремене књижевне токове са новим животним реалностима које су створене појавом интернета и животом на њему. Анализом његовог блога и приказом основних теоријских поставки даје се увид у трендове савремене књижевности, али и у нове форме живљења и рада савремених аутора.

Кључне ријечи: интернет-књижевност, блог, нови реализам, кибернетски реализам, ескапизам.

Иако је слика пјесника, пријатеља богова, луталице и странца у овом свијету, највише потенцирана у романтизму, а у неким облицима је остала и до дана данашњег, она постоји заправо од када постоји и сам појам 
умјетности и умјетника. Умјетник је тај који види оно што други не виде, који у простору обраслом шибљем и грмљем види уређене стазе и грађевине, који у громади камена види тијело које треба ослободити, који у неуобличеној хрпи глине види Адама, а у бјелини празног папира види склад ријечи и мисли. То виђење другог свијета претпоставља и живот на граници, извјесну неприлагођеност овом свијету, која се у екстремнијим ситуацијама огледала у неуротичном повлачењу из њега и животом изгнаника. Сјетимо се само Хелдерлина [Hölderlin] (1770-1843), који је тридесет и шест година, дакле половину свога живота, провео као добровољни затворник у једној кули на обали Некара у Тибингену. Његовом заслугом настаје слика умјетника који живи у кули од слоноваче, а која постаје симболом свијета умјетника и његовог ескапизма.

У лексикону страних ријечи и израза ескапизам се дефинише, осим као удаљеност од стварности (њем. Realitätsferne), и као држање тј. став (њем. Haltung) одн. одбрамбени став (њем. Abwehrhaltung). ${ }^{1}$ (WahrigBurfeind, 2011: 280) Овај одбрамбени став, колико је иманентан самом умјетнику и умјетничком стварању, толико је и индукован његовим окружењем. Спољашњи свијет представља опасност, причињава непријатности или једноставно не нуди задовољство које може да понуди свијет маште и умјетник га оставља правећи свијет за себе.

Индустријализацијом и развојем градова настају нови, до тада непознати, облици живљења. Град више није трговачко и управљачко средиште, него и мјесто живота милиона људи и врло често потпуно различитих и супротстављених друштвених група. Живот у

1 Све цитате и називе је превео аутор рада. 
градовима није само удобан, него умногоме постаје и туробан. Многи пјесници доживљавају град као чудовиште које прождире људе. У Рилкеовом [Rilke] кратком роману Die Aufzeichnungen des Malte Laurids Brigge (срп. Записи Малтеа Лауридса Бригеа) млади дански аристократа Бриге лута Паризом са почетка двадесетог вијека, који у његовим очима никако није град свјетлости, него санаторијум за умирање. Људи су у гротлу великог града. Звукови трамваја поврјеђују слух. Из таквог града људи бјеже у природу, тражећи у њој изгубљену идилу. Или се завлаче у своју собицу, у библиотеку, бјеже у књиге, у писање, налазе смирај у прошлости.

Необична судбина задесиће писце који нису успјели да побјегну из нацистичке Њемачке, а код којих је постојало неслагање са нацистичким режимом. Код њих се може примјетити појава која ће се описати као стање унутрашње емиграције - повлачење и бијег од друштва и државе. Писци као што је био Вернер Бергенгруен [Werner Bergengruen] бјеже у форму историјског романа, али се у тим дјелима може јасно препознати критика националсоцијалистичког режима, па макар то било у контроверзном односу какав је имао Ернст Јингер [Ernst Jünger].

Бијег у друге свјетове, бијег у друге државе, бијег од свијета уопште, чини се да је ескапизам други назив за умјетност одн. књижевност која неће да се потчини власти овога свијета и која хоће да сачува слободу и аутономију. Међутим, историјске форме ескапизма не остају исте и мијењају се с обзиром на услове живота умјетника.

Појавом нових медија почетком двадесетог вијека, посебно филма, а затим и телевизије, ескапизам постаје много уочљивија појава с обзиром на то да се 
може примјетити не само код умјетника, него и у другим друштвеним групама. Нови медији подстичу масовни конзумеризам, а он пак изазива масовне појаве као што је бијег од стварности у свијет нових медија. У великој мјери све ово важи и за конзумирање садржаја са интернета.

Појавом интернета, који је свакако најважнија технолошка иновација краја двадесетог вијека, није се само десила промјена у начину комуникације међу људима, него се појавио и простор који омогућава мноштво других, до скора непознатих, социолошких и психолошких појава. Катарина Кацер [Catarina Katzer] у дјелу Cyber Psychologie. Leben im Netz: Wie das Internet uns ver@ndert (срп. Сајбер-психологија. Живот на мрежи: Како нас интернет мијен@) (2016) анализира низ појава које доноси конзумација интернет садржаја. Интернет је донио феномене као што је нпр. немогућност разликовања стварних и виртуелних садржаја, погрешно поимање информација, тешкоћа раздвајања приватне сфере и јавности, овисност од конзумирања интернет садржаја итд.

Свакако да је интернет остварио велики утицај на поимање идентитета савременог човјека, а уведена је и култура самоинсценирања одн. стварања сопствене слике о себи на интернету, посебно на социјалним мрежама. Људи бјеже у виртуелне свјетове преузимајући на себе идентитете који не морају имати никакве сличности са стварним и ствара се један нови вид ескапизма.

Писци користе интернет као мјесто за продају и пласман својих дјела, као мјесто за рекламу и најаве наступа, али и као мјесто за стварање потпуно новог књижевног жанра - интернет-књижевности. Интернет-књижевност не чини само оно дјело које је објављено на интернету, него је то прије свега књижевност која 
користи потенцијале интернета у поетичке сврхе. Данашња интернет-књижевност је углавном блог-књижевност, односно она књижевност која користи одређене потенцијале блога, који је специјално дизајнирана страница на интернету намијењена за вођење дневника (в. Петровић 2018: 58).

Из мноштва књижевних блогова на њемачкој књижевној сцени издвојићемо онај најрадикалнији. Ради се о књижевном блогу аутора Албана Николаја Хербста [Alban Nikolai Herbst], под називом Die Dschungel. Anderswelt (срп. Џунгла. Другосвијет)2. Хербст још од октобра 2003, када је објавио свој први прилог, непрекидно пише свој књижевни блог. Изглед његовог блога не разликује се од стандардног изгледа било ког другог блога. Насловна страница је подијељена на три дијела. У горњем дијелу, водоравно постављена, стоји илустрација са сликом дрвећа у џунгли и текстом „Die (neue) Dschungel. Anderswelt“ (срп. „(Нова) Џунгла. Другосвијет“), затим „Dschungelblätter“ (срп. „Листови џунгле“), а затим и посвета, и линкови ка најважнијим Хербстовим пројектима. Испод тога је екран подијељен на два вертикална дијела. Један већи са прилозима и други, мањи, са линковима ка најновијим издањима, статистикама, посљедњим коментарима, категоријама, архиву итд.

Аутор блога не преузима на себе обавезу да његов блог буде на било који начин кохерентан. Зато је овај блог готово немогуће препричати, па ни навести теме којима се бави, јер их има мноштво. Аутор користи блог за прелиминарно објављивање садржаја који ће се касније наћи у његовим штампаним издањима,

2 Интернет-адреса: https://dschungel-anderswelt.de/; раније: http:// albannikolaiherbst.twoday.net 
али се не ограничава тиме. Велики дио блога чине аутопеотички садржаји у којима, заједно са читаоцима, учествује у дискусијама које би требало имати за циљ разјашњење појединих културних и умјетничких феномена, а понајприје интернет-књижевности. Све то је измјешано са свакодневним извјештајима из ауторовог живота, које он објављује под ознаком „Arbeitsjournal“ (срп. „Дневник рада“).

Као узорак можемо узети трећу седмицу у новембру текуће, 2018. године. Чланак од 12. новембра представља извод из једне приче из антологије Erzählungen $I$, која треба да изађе у прољеће 2019. године. Испод прилога, у виду коментара, налази се и кратка дискусија са корисницом @elfi око схватања појма јунака. Затим, 14. новембра, корисник Bruno Lampe (!) (вјероватно Хербстов алтере-его с обзиром да Хербст узима на себе више идентитета) објављује чланак инспирисан обновом фасаде цркве Sant'Agostino. Дана 15. новембра доноси извод из интервјуа професора са Харварда Стивена Пинкера [Steven Pinker] за Neue Zürcher Zeitung, заједно са линком ка комплетном интервјуу. Тема је једнакост полова и феминизам, а у коментарима Хербст даје линк ка прилогу у којем он расправља о истој теми. Већ 16. новембра објављује радни дневник. Као што је уобичајено, Хербст као раноранилац свој дневник почиње у 7:18 (а врло често и раније) уз кафе макијато. Чак ни овај есеј од 1.500 ријечи не показује никакву тематску кохерентност, него представља гомилу набацаних размишљања и линкова. Сутрадан објављује чланак под насловом „Повратак прелазном објекту“3 $у$ коме описује један сан, а 18. новембра линк према магазину Diaphanes у коме је и Хербст објавио своје радове.

3 „Rückkehr zum Übergangsobjekt“ 
Можемо рећи да је ова седмица репрезентативна за цио блог. Изводи из дјела, линкови, дискусије са читаоцима, коментари, рецензије, дневничке забиљешке, све то Хербст биљежи невјероватно екстензивно и минуциозно већ деценију и по. Свакако је најзанимљивији дио блога онај његов ауторефлексивни одн. аутопоетички дио. У њему се открива Хербстов однос према умјетности и откључава се загонетка оваквог приступа књижевном стварању с обзиром да, по Хербсту: „У књижевном блогу прожимају се приповједање, његова поетологија и теорија продуктивности“" $(2011: 25)$.

Хербстови поетолошки погледи сабрани су у дјелима Kleine Theorie des literarischen Bloggens (срп. Мала теорија литерарног блогована) (2011.) и Kybernetischer Realismus (срп. Кибернетски реализам) (2007.). Ни једно ни друго дјело нису систематизоване поетике него компилације теорија о књижевном стварању и књижевности уопште, коментара прилога на блогу, извода из предавања са Универзитета у Хајделбергу (тзв. Heidelberger Vorlesungen), а све под мотом: „Истовремено писати поетику и бивствовати“" (исто: 46), јер: „Испод овог захтјева након модерне и постмодерне није више прихватљива ниједна естетичка теорија, која се може узети за озбиљно“б (исто: 46).

Читалац никада не може бити сигуран у облик егзистенције аутора и ликова које аутор уводи на блогу. И аутор, и други учесници на блогу могу свјесно да узимају друге идентитете, да се поистовјећују са њима и да тиме граде један други свијет. Учесници у стварању

4 „Im Literarischen Weblog greifen Erzählung, ihre Poetologie und Produktivitätstheorie ineinander."

5 „Eine Poetik zugleich verfassen und s e in.“

6 „Unterhalb dieses Anspruchs ist nach Moderne und Postmoderne keine ernstzunehmende Ästhetische Theorie mehr akzeptabel.“ 
блога тиме постају аватари, које Duden дефинише као „виртуелни умјетнички лик у сајбер-простору“.7

Са једне стране имамо један свијет који се ствара на интернету, виртуелни свијет који Хербст изједначава са фикцијом, а са друге стране, ту фикцију креирају и у њој учествују стварни људи. Тај свијет не мора да буде ни искључиво фиктиван, ни искључиво фактичан. За Хербста, блог стоји на граници свјетова, стварност и фикција губе оштре границе (Herbst 2011: 7). Управо то прожимање чини поетичку основу блога. Прожимајући једне и друге ствара се „слика могућих стварности, онако како их види Џунгла“" (исто: 39).

Видимо да је однос према стварности код овог савременог књижевника-блогера сасвим другачији од оног који је био код аутора који су из стварности бјежали у фикцију. Хербст истиче: „Не ради се о томе да се стварност замијени. Баш насупрот томе. Ради се о томе да се она још надопуни, да јој се још нешто придода, да се обогати. Ради о постизању што веће пуноће“9 (исто: 126). Дакле, фикција као надоградња стварности не треба да постоји као издвојени свијет него стварност и фикција морају бити у сапрожимању и синергији.

Ова поетолошка поставка аналогно води ка другој, а то је да на књижевном блогу, онако како га Хербст види, живот прелази у роман, а учесници на блогу постају ликови из романа. Тај роман симулира стварни живот: нема краја, дописује се, враћа се на претходно, садржаји се линкују један према другом и ка садржаји-

7 „virtuelle Kunstfigur im Cyberspace“ (https://www.duden.de/node/ 790319/revisions/1857093/view) (датум приступа: 05.12.2018.)

8 "das Bild möglicher Wirklichkeiten, wie Die Dschungel sie meint.“

9 „Es geht nicht darum, die Realität zu ersetzen. Im Gegenteil. Es geht darum, sie noch anzufüllen, ihr etwas Weiteres hinzuzugeben, sie reicher zu machen. Es geht um die möglichst große erreichbare Fülle.“ 
ма ван блога (због тога овај блог и носи назив Џунгла), учесници као и сам Хербст узимају на себе мноштво идентитета и сви заједно праве роман (в. исто: 41).

Хербстов рад не пролази без критике стручне јавности. Мјеста за критику свакако има с обзиром на Хербстова поприлично поједностављена схватања књижевно-теоријских појмова и на њихову промјенљивост пошто Хербст не осјећа обавезу да се везује за дефиниције. Бобцин [Bobzin] посебно напомиње Хербстово схватање књижевне фикције и ликова. Пошто неко узме одређени виртуелни идентитет и учествује у једном књижевном експерименту не мора да значи да је он истовремено и књижевни лик. Књижевног лика одликује посебна врста зависности од окружења у којем се налази у књижевном дјелу, што није случај са стварном личношћу која је створила неки аватар, иако се у процесу рецепције може стећи такав утисак (в. Bobzin 2015: 378-390).

Без обзира на врло оправдану критику, Хербстов рад засигурно помјера границе књижевности. Међутим, то помјерање није до те мјере радикално како би га он сам желио представити. Оно што Хербст ради још је један у низу аутофикционих експеримената који има своје и формалне и садржајне специфичности и уклапа се у пост-постмодерне трендове у европској књижевности који се називају новим реализмом (в. Meier 2017).

Нови реализам покушава да пронађе нови однос према иронији. Овај однос је централно питање прозе од времена модерне до данас. Тај однос се у новом реализму остварује тако што се он неће ослањати на превазиђене концепте реализма деветнаестог вијека, нити ће да лебди у произвољности постмодерне, него ће да доведе књижевност у нову позицију према иронији и стварности. 
Кибернетским реализмом, како Хербст назива свој књижевни експеримент, уз помоћ нових технологија, доводећи особине интернета одн. блога до екстрема, прави се и нови иронијски однос. Он се ствара управо на том напону, између бјежања из стварности и жеље да се на ту стварност утиче. Кибернетски реализам, као један вид савременог ескапизма, представља бијег од стварности уз покушај да се интегрише стварност у умјетност и обрнуто. Интеграцијом стварног и фиктивног свијета избјегава се, са једне стране, банализација, а са друге стране задовољава се потреба да се умјетност укоријени у стварности.

Видјели смо да се умјетности генерално може приписати ескапистички карактер. Књига и фикциони свијет одувијек су били земља у коју је бјежао не само аутор, него и читалац. У великој мјери стварност одн. окружење аутора и читаоца проузрокује ескапистичке тенденције или пак пружа могућности за бијег. Милионски градови у којима се људи често осјећају усамљеним и одбаченим, те савремени начин живота, стварају идеалну климу за ескапизам, а интернет као медиј пружа прилику да се он и оствари. Пружена је могућност да човјек може да заодјене свој стварни идентитет у виртуелни и да живи неку врсту паралелног живота са постојећим. То је ескапизам у коме није потребно да побјегнемо из физичког окружења које нас притишће. Довољно је само да се укључимо на мрежу и бијег је успио, а с обзиром да смо на мрежи непрекидно и да имамо уређаје од којих се не одвајамо и тај бијег је непрекидан.

На крају можемо закључити да Албан Николај Хербст, коришћењем интернета и нових технологија одн. књижевно-умјетничким стваралаштвом на блогу, даје том бијегу један сасвим нови квалитет, а као аутор 
и теоретичар кибернетског реализма као вида новог реализма преиспитује границе умјетности и књижевност, те доприноси новом усмјерењу књижевности у доба након постмодерне.

\section{Извори и литература}

Ainetter, S. (2006). Blogs - literarische Aspekte eines neuen Mediums. Wien - Berlin: LIT-Verlag.

Bobzin, H. (2015). Von Bremen in die Anderswelt. Über Identität und Realität in Prosahauptwerk, Poetik und Weblog von Alban Nikolai Herbst. Dissertation. Göttingen: Philosophische Fakultät der Georg-Albrechts-Universität.

Bonfadelli, H. (2004). Medienwirkungsforschung I: Grundlagen und theoretische2004 Perspektiven. Stuttgart: UTB.

Der Brockhaus Literatur. Schriftsteller, Werke, Epochen, Sachbegriffe. (2010). Gütersloh/München: wissenmedia.

Duden Wörterbuch. (05. 12 2018). Von https://www.duden.de/ Herbst, A. N. (2008). Kybernetischer Realismus. Heidelberg: Manutius. Herbst, A. N. (2011). Kleine Theorie des literarischen Bloggens. Bern: Edition Taberna Kritika.

Herbst, A. N. (25. 08 2018). Die Dschungel. Anderswelt. Von https://dschungel-anderswelt.de/

Herbst, T. (2013). Eskapismus durch Serienkonsum: Der Einfluss von Online Streams auf suchtartiges Verhalten. Hamburg: Diplomica Verlag.

Katzer, C. (2016). Cyber Psychologie. Leben im Netz: Wie das Internet unsver@ndert. München: dtv.

Meier, A. (2017). Postmoderne: Philosophie - Literatur. Kiel: Christian-Albrechts-Universität .

Rilke, R. M. (1980 (1910)). Die Aufzeichnungen des Malte Laurids Brigge (Bde. III-1). Frankfurt a. M.: Insel Verlag.

Wahrig-Burfeind, R. (2011). Brockhaus WAHRIG-Fremdwörterlexikon. Gütersloh/München: wissenmedia.

Душанић, Д. (2012). Шта је аутофикција? Кюижевна исторuja, 44, $797-810$. 
Петровић, А. (2018). Поетика дневничког романа. Необјавлена докторска дисертација. Пале: Филозофски факултет.

Aleksandar V. Petrović

\section{KYBERNETISCHER REALISMUS UND GEGENWÄRTIGER ESKAPISMUS}

Heutzutage, wenn die Städte sich so ausbreiten, dass die Flucht aus ihnen nicht mehr möglich ist; wenn selbst die Überreste der Natur so eine große Gefahr darstellen, fast wie die Stadt selbst, wird das Internet zu einer Plattform, auf der der moderne Eskapismus möglich ist. Der deutsche Schriftsteller-Blogger Alban Nikolai Herbst gibt in seinem literarischen Blog Die Dschungel. Anderswelt ein Beispiel für den gegenwärtigen Eskapismus. In seiner Theorie des kybernetischen Realismus bringt Herbst viele kreative und innovative Einblicke in die Literatur des neuen Realismus und verbindet zeitgenössische literarische Trends mit neuen Lebensrealitäten, die durch die Entstehung des Internets und durch das Leben darin geschaffen werden. Durch die Analyse seines Blogs und Darstellung der theoretischen Grundlagen wird ein Einblick in die Trends der zeitgenössischen Literatur, aber auch in die neuen Lebens- und Arbeitsformen zeitgenössischer Autoren, geschaffen.

Schlüsselwörter: Internet-Literatur, Blog, der neue Realismus, Kybernetischer Realismus, Eskapismus. 